\title{
カイト・サイトーレヴァント地方先土器 新石器文化の一側面
}

藤 井 純 夫

ABSTRACT Sumio FujII, "Kite Site" - Another Aspect of the Levantine Pre-Pottery Neolithic: The research on the Levantine Neolithic has long focused on the districts more or less favored by the Mediterranean climate, such as coastal regions, Jordan valley, or upper Euphrates basin. In this decade, however, the informations on the prehistory of inland Levant have increased at an accelarating tempo owing to some area studies carried out in Azraq basin, Palmyra basin, Transjordan Black Desert, and so on, which present some new, important problems. That is the case of the so-called "kite site" or "burin site". In this paper the author introduces some new data and makes a short discussion on the former type of interesting site.

"Kite site", hunting trap in desert, consists of two main parts: an enclosure and two (or more) long guiding walls converging to it. It shows very wide distribution from inland Syria, Black Desert, to Sinai or northern Saudi Arabia. According to the flint remains such as Amuq or Byblos type points collected inside or just around the enclsure, it is quite possible that some of kites are dated to the Pre-Pottery Neolithic B period, as is in the case of "burin site".

In contrast to the rather limited perspectives so far described on the neolitization of the Levant, it is now more and more clear that the Levantine Pre-Pottery Neolithic B, the later stage in particular, consists of the following three versions interacting with one another; firstly, more or less sedendary farmer communities in fertile regions penetrated from the northern Syria and eastern Anatolia, secondarily, temporary harvester/hunter groups around the oases in the intermediate areas, and lastly, migrating, but, flourishing hunters of gazelle and other steppic games in inland step who seem to have been influenced from the

* 岡山市立オリエント美術館学芸員 
Pre-Pottery Neolithic farmer communities in the western regions, but basically originated in the preceeding Natufian and Pre-Pottery Neolithic A gazelle hunters.

\section{1.はじめに}

レヴァント地方に扔ける先土器新石器文化の研究は, 地中海性気候の影響下 にめって植生に比較的恵まれた地域, すなわち海岸部, ヨルダン渓谷, ユーフ ラテス上流域などを中心に進展してきた。初期農耕文化の解明を目的とする研 究である以上，それも当然であったろら。また，発掘調査に伴う諸般の便宜を 考光れば上記の地域が専ら選択されてきたのも無理からぬことと思われる。乙 かしその結果, レヴァント地方の先土器新石器文化に対する我々の理解は一 後述するよらに，内陸部の調查が進んできた今となっては一いささか片手落 ちのものとなってしまったように思われる。

ここ十年来，トランスョルダン，シナイ，ネゲブ，サウジアラビア北部，シ リア内陸部などで活発化してきた調査・研究によって，上述の歪みなり偏りな りを補正する重要な資料ろ゙得られつつある。「中原」の地域だけで構成されて きたレヴァント地方の先土器新石器文化像に「漠北」の光が差してきた訳であ る。何よりもまず, 先土器新石器文化の分布域が著しく拡大された。「中原」 に和いて展開された農耕と家畜飼養を基幹とする定住村落型の先土器新石器文 化に対して，それとは全く異質の，いわば内陸型の先土器文化が前者の後背地 に広く分布していたことが徐々に明らかになってきたのである。しかし内陸型 先土器文化と一口に言ってもその内容は決して一様ではなく, 様々な様相を呈 している。その中で最も関心を集めているのが，ビュラン・サイト (burin site) とカイト・サイト (kite site) であろら。ビュラン・サイトとは彫器 (burin) が 二次調整の認められる石器群 (retouched tools) の中で極めて高い比率を占める という点で特異なアセンブリッジの遺跡でめるが，これについては別の機会に 発表を予定している（藤井1987）。小稿では後者のカイト・サイトについて研 究の現状を概観し，幾つかの問題点を指摘すると共に，それに対する予備的な 考察を試みたい。

\section{2. カイトの構造と機能}

カイト・サイト (kite site) とは正に文字通り, 凩状プランの大型遺構 (kite) 
を伴ら遺跡 (site) のことである。“kite”は別名“desert kite”とも称される。こ のように一風変わった名称が採用されたのは, カイト・サイトが飛行機のパイ ロットたらによって初めて発見・報告されたからである (Maitland 1927, Rees 1929)。1920年代の初頭にカイロ=バグダッド間の航空路が開設され, それに 従事したパイロットたらが砂漠の中に奇妙な遺跡を発見し, 空から見たその形 が子供の遊ぶ凩に似ていることからこのように名付けたのであった。全長数 $100 \mathrm{~m}$ に及ぶ大遺構であるから, 空から俯瞰しなければ平面形を第一感とした こうした名称も生まれなかったかも知れない。

カイト・サイトは凩と同様，基本的に二つの部分によって構成される。まず 凩の本体に相当するのが “enclosure” と称される石積みの囲い場，次いで凩の 脚に当たるのがこの本体部分から長く伸びた二本（或は数本の）石積みによる 誘導壁 “guiding wall”である。実例の中から代表的なものを幾つか紹介して みよう。

図 1 はシナイ半島西部, アラュィフ・エン・ナカ山 (Jebel 'Arayif en-Naqa) の南で発見されたカイトである。ワディ支流の斜面に位置している。二本の誘 導壁はそれぞれ，200m，300 m余りの長さで斜面等高線に平行あるいは垂直に 伸び，東側に向かって開ロしている。一方この二本が収束する西側部分には $8 \mathrm{~m}$ 前後四方の矩形の囲い場が設けられている。囲い場の入り口部分は小規模 の崖を形成しており，比高 $8 \mathrm{~m}$ の高低差を有している。なお，囲い場の石積み は現在 $1.2 \mathrm{~m}$ の高さを残している。

図 2 はサウジアラビア北端の遺跡 Site 200-9 で確認されたカイトである。 $300 \mathrm{~m}$ 前後の誘導壁が北北東に向かって緩やかに上りながら収束し，その末端 に今度は下りながら円形プランの囲い場が築かれている。囲い場の周囲数箇所 にはニッチ状の小部屋が付属している。

図 3 のカイト（ヨルダン領黒砂漠，K.2.1）は星型の囲い場を有する。その 壁面屈折点には図 2 と同様のニッチ状小部屋が設けられているが，それには一 部屋のものと二部屋のものとがある。二本の誘導壁の中に更に数本の誘導壁が 認められるが，これと他の部分との時期関係は明らかでない。

以上の事例に示されているように，大きく開口する二本の誘導壁が徐々にそ の幅を狭め, 最後には数 $\mathrm{m} な い し$ 数 $10 \mathrm{~m}$ 幅の入り口を境に各種プランの囲い場 に至るといらのがカイトの基本的構造となっている。

ではこの奇妙な遺構の用途は何であったろらか。家畜の囲い場・避難場 (Rees 
1929, Harding 1953, Yadin 1955) とか, 水利施設兼牧草地 (Helms 1976) と か, 発見後, 様々な説が提示されたが現在はほぼ一定の結論に達している。す なわら，一定ルートを通ってステップを大群で移動するガゼルなどの草食獣を 一括して, しかも効率良く捕獲するための狩潅施設であるというのが今日得ら れている一般的な結論である (Field 1960, Rothenberg 1972, Meshel 1974, Helms 1981，Betts 1982，1983，1984，1985)。その根拠としては19世紀及び20世 紀初頭の民俗誌的記述の他に, 各種の岩刻画に表現されたカイト使用風景（図 4) などが挙げられて拈り，一部のカイトを除壮ばこの説が添ぼ確定的と思わ (1) れる。

\section{3. カイト・サイトの分布}

各地域に括ける調查内容に極端な精蹯があって, 総合的な分布図はまだ製作 されていない。ここでは二三の分布図を参考にカイト・サイトの分布の特徵を 把握するにとどめる。

さて現在最も調査が進んでいるのは, トランスヨルダンの砂漠地帯, 特にヨ ルダン領黒砂漠 (Black Desert) である（図 5 )。この地域に和ける分布調査は 一一その当初は別としても一全て低空からの航空写真測量によるものである。 従って広範囲に成果が上がってはいるるのの, 地上に拈ける綿密な測量は伴っ ていない。そのためか正確な遺跡件数は記載されていないが，図で見る限り優 に百件を越えるカイト・サイトが確認されているようである。いずれるワディ に添って列をなして拉り，一定方向を向いているのが特幑である。カイト・サ イトはこのヨルダン領黒砂漠に执いても最も濃い分布を示し, これより以南・

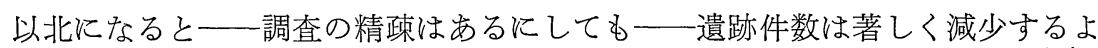
うである（ただし，シリア領黒砂漠にはかなりの件数があるものと思われる）。 ではカイト・サイトの分布はどこまで確認されているかといらと，現段階では 内陸部シリア（パルミラとホムスを結ぶ地域一帯）がその北限のようであり, 対する南限はシナイ半島東北部のやや海岸寄りの地域, あるいはサウジアラビ ア領黒砂漠に求められるよらである（図 6)。中でもサウジアラビア北辺地域 についてはかなり組織的な分布調查が実施されているので, そのデータは信頼 度が高い(Adams et al. 1977, Parr et al. 1978)。それによればサウジに和ける カイト・サイトの分布域はヨルダン領から続く黒砂漠だけに留まらず，さらに ネフド砂漠北部（Ha'il 地方）にもごく僅かながら及んでいるようである。 
以上述べたように，カイト・サイトは黒砂漠の中央部・北部を中心にレヴァ ント地方の内陸部に広く分布している。これよりも東側ではあまり調査が実施 されていないが，少なくとも中心地帯ほど濃くは分布していないものと思われ る。一方の西側に注目したい。地中海性気候に育まれたこの地域一帯は初期農 耕文化期はもちろん，それ以後も常に一貫して人々の居住するところであった。 また最初にも述べたように，内陸部に比べてはるかに遺跡調査も進んでいる。 にも拘らずこの地域からは今のところカイト・サイトの報告が無いのである。 従ってカイト・サイトはレヴァント地方全域に分布しているのではなく，好ん でその内陸部に限定されている遺跡と言えるであろう。これがカイト・サイト の分布の特徵である。

\section{4. 型式分類と出土遺物}

カイトの型式分類については，囲い場の立地形態执よび平面形を基準にする のが最も簡便であろう。なぜなら誘導壁の方はその形態に大きな変差が認めら れず，多くは単に立地条件に左右されているにすぎないからである。な牧，航 空写真に大半の資料を依存する現段階では細部の把握は不可能, 従ってここに 示す分類はあくまでも試案であり，見通しに過ぎないことを和ことわりしてお きたい。

（1）囲い場の立地一—これについては，(a)連続地形型，(b)陥穴型，の二種が 認められる。前者は緩やかな地形の変化をそのまま利用し, その上に石を積ん で囲い場としたものであり（図 $2 ， 3$ ），後者はワディの侵食によって形成さ れた崖の端に囲い場を設定したものである（図 1)。

（2）团い場の平面形一一平面形は，(a)円形・楕円形，(b)矩形，(c)星形，(d)乞 の他不定形, の四つに大別できる。更に言えば, 囲い場の壁面に和ける小部屋 の有無およびその数などによって細分類が可能であろう。

（3）囲い場と誘導壁の傾斜一ーカイトを構成するこの二つの部分がどのよう に傾斜しているか，つまり獲物となる動物が誘導壁に囲まれた三角形の区画を 疾走して囲い場にまで至るまでにどのような高低差があるかによって，(a)水平 型（図 1)，(b)駆け降り型，(c)駆け上り型（図 3)，(d)屈折型（図 2)，などの 差が認められる。もちろん地形によってはより複雑な経路があり得るだろらが, 基本的にはワディに対してどら向いているかが上記の差になって現れているも

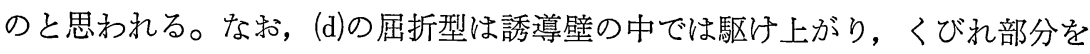


境に囲い場に入って駆け降りるものが多いようである。このことは図 3 のよう にたとえ駆け上がり型であっても，射手の隠れ潜んでいる小部屋だけは反対側 下降斜面に設けている事例と関係があるように思われる。すなわち，敏感な草 食獣に対して，人間の姿をなるべく見せまいとする配慮であろら。

(4)誘導壁連結の有無一一イトには, (a)単独型，(b)連結型，の二種がある。 カイト 1 基が単独で存在しているものが(a)，これに対して誘導壁の入り口側先 端部が隣のカイトのそれと連結し, 全体として数基ないしは数十基の “kite” 群 を成しているものが(b)である（図 7 )。

カイトの型式分類に際して基準となるのは以上の諸点である。実測資料数が 少ない今の段階ではこれら各型式ごとの分布の特徵を示すことは困難である。 ただ見通しとして述べるならば，1-(b)，2-(a)，3-(c)，4一(a)のタイプ （つまり, 陥穴型, 円形型, 駆降り型, 単独型) はシナイ半島に多く見られ, 1一(a)，2-(c)，3-(b)(d)，4-(a)(b)のタイプ（すなわち, 連続地形型, 星状, 駆け上がりあるいは屈折型, 単独あるいは連結型) が黒砂漠一帯に多いと言う ことができるであろう。

本来ならば次にカイト各型式の編年について述べるべきであろらが，実際の 現地調査によって共伴の遺物・遺構があまり明らかになっていない今の段階で はそれは到底不可能である。また現地調查が実施された場合においても，遺物 を殆ど伴わないことがカイトの特徴でもあるから大半のカイトは年代不明と言 ってよい。年代の明確な遺構が隣接している場合に限って, それとの切り合い 関係から上限ないしは下限が設定できるに過ぎないのである (Helms 1981)。そ うした事例について逐一述べる余裕は無いので, ここでは若干の現地調査によ って検出された共伴遺物について検討し，ごく一部ながらカイトの時期比定の 根拠としたい。

まずカイトと遺物の共伴関係について留意しておかねばならないことは，誘 導壁の内側のような広、範囲内で出土した遺物はカイトとの関係を一概に設定 し得ないといらことである。カイトの共伴遺物と言うなら少なくとも囲い場内 部, 或はそのごく周縁の出土であらねばならない。こうした基準を満たす遺物 としては次のようなものがあるに過ぎない。

ヨルダン東部, カア・メジャラ地方 (Qa'a Mejalla) の小型カイト・サイト (Site 1b) では囲い場部分の内側から石器が数点出土している。石刃 3 , 小型剝 片石核 1 , 両面加工石器 1 がそれである。実測図が添えられていないので詳細 
は摑めないが, 報告者によれば周辺のビュラン・サイトの石器と共通の特徴を 備えているという（Betts 1982）。またこの遺跡では囲い場の物影で押圧剝離の 発達した尖頭器 4 点も出土している（図 8)。その中には周辺地域にこそ類例 は無いが, シリア内陸部, エル・コウン (El-Kown) 地方のビブロス型尖頭器 に型式が似ているものがあると述べられている。更に, ワディ・ラジル (Wadi Rajil) なぞョルダン東部の幾つかの地域では, 星状プラン大型カイトの囲い場 の内外からアムク型尖頭器が出土することが多いと言われている（Betts 1983， 1984)（図 8)。

以上の限られた報告からは何一つ確実なことは言光ない。しかし先土器新石

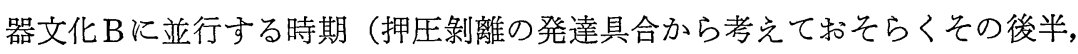
即ち紀元前 7 千年紀）に少なくとも一部のカイトが利用されたことは十分予測 できる。囲い場の内部ではないが，カイトの周辺にあって，しかもカイトとの 有機的な関係を示す円形住居址やビュラン・サイトなどの遺跡から出土した遺 物をこれに加味すると, カイトの一部が先土器新石器文化 Bの後半に比定され ることはほ臣間違いないものと思われる。しかもとの数は予想外に多いように 思われるのである。だとすると紀元前 7 千年紀のレヴァント地方内陸部におい てカイトの果たした役割は実に大きいと言わねばならない。筆者がこの奇妙な 遺構に注目しているのも正にそのためである。

\section{5. カイト周辺の遺跡}

カイトの時期比定を補足する意味で, カイト周辺の遺跡について簡単に検討 して扣きたい（図 9，10）。カア・メジャラの二つの地区で総合的な分布調査 が実施されているので，これを参考に検討してみよう (Betts 1982)。

まず，第 1 地区（Qa'a Mejalla 1) では 2 基，第14地区 (Qa'a Mejalla 14) では 1 基のカイトがそれぞれ確認されている（な拉，第 1 地区の site $1 \mathrm{~b}$ は先 述したよらに, 押圧剥離の尖頭器を出土した囲い場である。従ってこのカイト は先土器新石器文化B並行の遺構と考元られる)。これらのカイトの周辺には 各種の円形住居址 (hut circles), 石器製作・加工址 (knapping site), ビュラン・ サイト，くらげ状遺構 (jellyfish) など様々な性格の遺跡が分布しているが，そ の大半がカイトの背後或は側方に位置している点に注目したい。カイトの誘導 壁の内側に位置する遺跡（少なくとも住居址）は極めて少ないのである。カイ トの目的は誘導壁の中に草食獣を追込み, 囲い場で一網打尽にすることにある 
から，囲い場は勿論，誘導壁の内側にも住居があってはならない。むしろ囲い 場の後方や側面に位置していたほらが獲物の解体・運搬及び消費に好都合なの である。逆に言えば，こうした立地を示す遺跡の多くはカイトと同時期のもの であり，カイトと有機的な関係を有していたと解釈できるのではなかららか。

勿論, 遺跡の同時代性はこうした立地論だけでは確証できない。しかし上記 のカイト周辺遺跡ではナビフォーム型石核や押圧剝離による尖頭器など，レヴ アント地方の先土器新石器文化 B 飞特有の石器が出土しているので, 遺物の面 でもやはり紀元前 7 千年紀頃に比定し得るのである。またビュラン・サイトか らはその指標となる特定型式のビュラン (angle burin on retouched truncation) が数多く検出されている。この種のビュラン・サイトがレヴァント地方の先土 器新石器文化 B（特にその後半, すなわち紀前 7 千年紀）に属することはヨル ダン東部のワディ・ドバイ B (Wadi Dhobai B) (Waechter and Seton-Williams 1938) やシリア内陸部のエル・コウン地域 (Cauvin, J., Cauvin, M.-C., and Stordeur, D. 1979)，パルミラ盆地 (Akazawa 1979) などに扔ける発掘調查で確 認済みである。従って, こうした周辺遺跡の多くが先土器新石器文化 B（特に その後半）に位置付けられる以上，それらと関連を持つかに見觉るカイトの方 も同じ時代に属すると考えるのが自然であろう。Site $1 \mathrm{~b}$ 出土の各種尖頭器が その何よりの証拠と言えよう。

\section{6. レヴァント地方内陸部における先土器新石器文化の構造}

内陸型先土器新石器文化の遺跡の性格を分類し, 今後の研究の見通しを立て て技さたい。な括ここで対象とするのは，先土器新石器文化Bに並行の遺跡で ある。

第一に挙げられるのは，アイン・ガザル ('Ain Ghazal) (Rollefson 1984， Rollefson and Simmons 1984) 飞代表される定住農耕村落型の遺跡である。こ の他アアイン・エル・アサッド (Ain el-Assad) (Rollefson 1983) や，ヒルベト ・ハマーム (Khirbet Hammam) (Rollefson and Kafafi 1985) などの遺跡もこ れに近い性格のものかと思われるが，いずれも調查が部分的でその全体像はま だ掝めていない。ともかくもこれらの遺跡は湖や泉など, 内陸部のオアシスに 立地する点が特徵である。遺跡面積も比較的大きく, アイン・ガザルのように ヨルダン渓谷の大遺跡に匹敵するものも見られる。本格的な住居が営まれ, 遺 物の種類も豊富である。石器の内訳に関しても尖頭器, 鎌刃, 彫器, 削器, 搔 
器，石錐，石斧などを比較的バランス良く含み，ビュラン・サイトに見られる ような著しい偏りは示さない。また石臼・石杵など, 各種の穀物処理用具も完 備している。この種の遺跡は今のところトランス・ヨルダンの一部（それも比 較的ヨルダン渓谷に近い地域）でしか確認されていない。文化的にもパレスチ ナの先土器新石器文化 $\mathrm{B}$ に連なる性質のものである。アイン・ガザルに見られ る頭蓄骨崇拝がその最たる証拠であるが，その他にもジェリコ型尖頭器の多用， $\mathrm{A}-\mathrm{I}_{3}$ 型及び $\mathrm{A}$ - $\mathbb{I}_{3}$ 型鎌刃（藤井1981，1983）の採用などにパレスチナ，特に ヨルダン渓谷に叔ける先土器新石器文化 $\mathrm{B}$ との強い関係が認められる。

前述した遺跡は内陸部と言ってもヨルダン渓谷との中間地帯に位置する遺跡 であるが，本来の内陸部にも農耕の存在を伺わせるものがある。ヨルダン領黒 砂漠のドゥウェイラ (Dhuweila, Site 2202), イブン・ェル・ガジ (Ibn el-Ghazzi, Site 3133)（Betts 1985）がとれである。しかしながらこの二つの遺跡では鎌刃 が出土していることを除いて，前者注どの積極的な材料は見当たらない。従っ て本格的な定住農耕村落とは言い難いが，短期的に穀物の収穫を行っていた可 能性は残されている。

これに対して, 内陸部固有の遺跡としてはカイト・サイト及びその周囲に拉 ける石器製作址，円形住居址，ビュラン・サイト，くらげ状遺構などが挙げら れる。こうした一連の遺跡は恐らくカイトを中心に成り立っていたものと思わ れる。現在全く砂漠化しているこの内陸部も紀元前 7 千年紀の比較的湿潤な環 境の下では多少ともステップ化したと言われているが (Garrard et al. 1985)， そのステップの中を群孔を成して，乙かも一定のルート(即ち一定のワディ) を通って季節移動するガゼルなどの草食動物を待ちかま光, 或は追跡し, カイ トによって一網打尽にすることによってこれらの集団が維持されていたと考兄 られるのである。だとするとこれらの集団の経済基盤はレヴァント地方の西部 地域で発達しつつあった農耕とは执よそ対象的な移動性の集団狩猟にあったと 言わねばならない。その意味では内陸部のこうした先史文化に対して, 先土器 「新石器文化」といら用語を用いるべきではないかも知れないが，時代の指標 となる石器だけは部分的ながらも明確にレヴァント地方西部の定住農耕文化と 関係しているのでこの用語を用いてきた訳である。

以上述べてきたように, レヴァント地方の先土器新石器文化 $\mathrm{B}$ の時代（特に その後半）は，西の地中海性気候地帯から東の内陸性気候地帯に順を追って， 定住性農耕文化，半定住性農耕文化，移動性狩編文化がそれぞれ並行して展開 
していた時代である。勿論, その分布は西から東に向けて整然としていた訳で はない。地域の小環境を反映してモザイク状の複雑な形を示していたであろら が，天水農耕が可能かどらかによって全体としてはほぼ上記のような区分を生 じていたと考觉らる。

ではこの三者間の関係はどう解釈すべきであろらか。それぞれの環境条件に 適合した全く別個の文化と見做すべきか，それとも同一の集団による季節的な 生業形態が三つの異なった形となって現れていると考觉るべきか。現段階では この問題に対する答えは用意できない。しかしトランスヨルダンのアズラク盆 地のような地域には，定住性農耕村落 (“Ain el-Assad) と移動性狩猟集団 (Jabal Uweinid) (Rollefson and Fröhlich 1982) との共存関係が認められるよらに思 われる。だとするとこの両者はそれぞれ文化系統の異なる別個の集団と考党る のが妥当かも知れない。もちろん両者の区分は厳然と固定されたものではなく， 中間地域の折哀的な遺跡を通して，相互の移動が繰り返されていたと考劣るべ きであろう。レヴァント地方の先土器新石器文化 Bが安定した発展を示し得た のも, こうした後背地の存在がバネになって全体の柔軟性を保ち, その収容能 力を高めていた働いていたことが一つの原因ではなかったかと思われるのであ る。

ところで, 内陸部の先土器新石器文化の所在に関してここで用いた「後背 地」といら言葉は適切でないかも知れない。なぜならそこには農耕文化中心の 見方が介在しているからである。旧石器時代, 特に終末期旧石器時代以降の狩 椫文化という観点からすれば，内陸部の先土器新石器文化の方こそがむしろ正 統的であり，技術の集大成の時期である。組織的で効率の良い狩猟を可能にし たカイトはその頂点に立つ遺構と言えるであろう。

いずれにせよ内陸部の先土器新石器文化は同時期における西側の農耕文化と は全く異質の文化であって，そこから派生した副次的な周辺文化ではなさそう である。むしろこの文化の出自はンヴァント地方固有の終末期旧石器文化（特 そナトゥーフ文化) とその後継である先土器新石器文化 A (Pre-Pottery Neolithic A) の中に求められるように思われる。その根拠としては次の二点が指摘でき よう。まず第一は, 内陸部の先土器新石器文化に和いては, 同じ時期の西側農 耕文化地帯に和ける矩形住居と全く対象的に, ナトゥーフ文化伝統の円形住居 が多用されているという事実である (Aurenche et al. 1981). 第二は, 内陸部 先土器新石器文化がガゼル中心の狩猟社会であるといら点である。ユーフラテ 
ス上流のテル・アブ・フレイラ (Tell Abu Hureyra) に抢ける動物遺存体の分 析によれば, この遺跡の場合, ナトゥーフ文化期及び先土器新石器文化前半 （ただし PPNB の前半の意）ではガゼルが優勢であるのに対して, 同後半から 土器新石器文化にかけてはガゼルが激減し代わってヒッジ・ヤギが中心になっ たことが報告されている (Legge 1975)。しかも同じ傾向はパレスチナに打いて も確認されていると言う。要するに, ガゼル中心の狩猟文化は極めてナトゥー フ的かつ（その後継である）先土器新石器文化 $\mathrm{A}$ 的な文化であり, それが内陸 部の先土器新石器文化に継承されていると考えられるのである。ただし, 内陸 部先土器新石器文化にも石器などの点で先土器新石器文化 $\mathrm{B}$ の影響が認められ ることは言うまでも無い。また,ナトゥーフ伝統の文化が内陸部のみで継承さ れていた訳でもなく, 多角的経済といら点ではむしろ中間オアシス地帯の文化 こそがナトゥーフ的と言えなくもない。内陸部の先土器新石器文化はナトゥー フ的と言うには余りに特殊化しているのである。その意味では, ナトゥーフ文 化の中から初期農耕の要素を切り捨ててガゼル狩猟のみに特殊化させたのが内 陸部の先土器新石器文化と言うことができよう。

以上のことから分かるように, 紀元前 7 千年紀のレヴァント地方は, 気候変 動によって再び移動性を高めていたナトゥーフ・PPNA 伝統の集団が再度の気 候湿潤化に伴って多少ともステップ化した内陸部に進出し，カイトに代表され る特異な狩猟文化を発達させる一方で, 西側の肥沃な地域にはシリア方面から 本格的な農耕文化が波及し(藤井1981)，この二つが中間的なオアシスの文化を 境に互いに並行して展開していた時代と考えられるのである。北からの PPNB 文化がパレスチナ在来の PPNA 文化を侵食征服したといら従来の単純な図式 だけではどうしても理解しにくかったレヴァント地方の紀元前 $8 \cdot 7$ 千年紀の 動向も, 上記の観点を採り容れて初めて正確に把握できるのではなかろらか。

\section{7.おわりに}

レヴァント地方内陸部に和ける特殊な遺構, カイト・サイトについて研究の 現状を概観し，今後の見通しを述べてみた。見通しはあくまで筆者の研究に係 わる部分に限定し, 他の点に関しては一切触れていない。しかしながらカイト ははじめにも述べたよらに今世紀初頭に至るまで連綿と築造・使用された施設 であるから, 先史考古学の領域に収まらない多くの問題を含んでいる。カイト による狩猟を核に培われた厳密な集団統制と移動狩猟民的な感覚, そしてそこ 
に発した特種な社会秩序は, カイトの分布域を故地とする後のセム系人種の基 層文化形成に大さな役割を果たしたものと考学られる。例えば，囲い網の中で 行われたアッシリアの狩編儀礼についても, セム系人種の故地で永く営まれた カイトによる狩猟と全く無関係とは思劣ない。この種の問題は暫く置くとして も, 先土器新石器文化 B並行のレヴァント地方内陸部がビュラン・サイトに代 表されるように予想を遥かに越えた多くの遺跡を有しているといら意外な現象 も，カイトによる極めて生産性の高い狩猟活動を想定して初めて理解できるの である。

最後に一つだけ述べて抢きたいのは内陸部の南北間に和ける関係の密接さで ある。カイト・サイト以上に広い範囲に分布し極めて均質な石器文化を有する ビュラン・サイトに見られるように，レヴァント地方の内陸部には相当に頻繁 な往来があったよらに思われる。それには移動性の高い集団がこの地域一帯に 生活していたことも関係しているであろらが，ともかくも内陸部の南北は遠距 離ながらも密接に連結しているようである。内陸部と西部との予想される東西 関係よりもそれは遥かに強い上らに思われるのである。ユーフラテス上流域・ 中流域から, シリア内陸部, トランスヨルダン, そしてアラビア半島北部に至 る広大な地域間には，予想外に活発な文化が展開し，交流していたと考えられ る。後世の遊牧民の移動ルートを見てもこらした内陸部間南北交通の頻繁さを 伺い知ることができよう(Prag 1985)。そしてこのことは，現在我が国の調査 団によって総合的な調查が実施されているパルミラ盆地の先史文化の解明に際 しても, 重要な示唆を与えてくれているょうに思われるのである。

注

（1）研究史については Yadin, 1955, Meshel 1974 に詳しく述べられているので，同 論文を参照されたい。

（2）シリア領黒砂漠の分布調查は進んでいない。Betts 1985 によれば，シリア南端に 位置するドゥルーズ山（Jeble Druze）を境に地勢が急変し，カイトの件数もこれに 応じて激減するとのととである。

（3） カイト設置面に㧍ける傾斜の問題は，カイトの築造に際してどのような地形が選 択されたかというだけでなく, カイトの水利施設論に対する検証という点であ重要で ある。即ち, 水利施設であるならばそのカイトは(a)の駆け降り型であらねばならない。 少なくとも，(c)，(d)の駆け上り型，屈折型のカイトは水之重力の性質に反しており， 水利施設ではあり得ない訳である。

なお,カイトの中には実際に水利関係施設のあのも含まれているようである (Helms 1976)。また今日でも, 火薬で岩に漥みを作り, その周辺の丘に石の誘導壁（ただし 
この場合は集水壁）を巡らせてとの窪みに水を集めるといった民俗例も報告されてい る (Helms op. cit.)。短期間の降雨，しかもそれが奔流となって消えてゆく内陸部に おいてての種のダムが果たした役割は決して小さくない。しかし駆け降り型のカイト の全てが水利施設という訳では無い。誘導壁はともかくとして，少なくとも囲い場の 壁面の防水だけは完全でないと保水の意味を成さないからである。その点では粗い石 積みによるカイトの大半はたとえ駆け降り型であったとしても水利関係の遺構ではな

く,やはり狩椫のための遺構と考えるのが妥当であろう。

（4）乙の点については狩猟対象動物の生態を基に次のような興味ある説明がなされて いる (Meshel op. cit.)。即ち, トランスヨルダン及びシリアの砂漠地帯に生息するガ ゼルは主として Gazella subguttorosa であるが, このガゼルは一定の季節に決まった 経路を通って大群で移動する。乙れに対してシナイ，ネゲブのガゼルは数十頭の群れ しか形成しない Gazella dorcas がその大半を占めていた。その結果，等しくカイトを 用いてもその狩編規模や方法が異なり, それがカイト自体の規模の大小や型式の差と なって現れているという説である。ただし先土器新石器文化当時の内陸部における動 物相はほとんど解明されておらず，僅かばかりの分析例 (A. N. Garrad, Appendix I: Faunal remains, In Betts 1985) があるに過ぎない。この分析の対象となった遺跡は必 ずしもカイト直結の遺跡ではないが, 内陸部の動物の中ではやはりガゼルが最も多く 狩诵されたととは確認できる。この中には動物遺体資料 102 片の全てがガゼルといっ た極端な事例む認められる (Site 2202, Dhuweila)。遺跡の性格によって多少の異動 はあろうが，いずれにせよ内陸部の先土器新石器文化でガゼルが主要な位置を占めて いたことは確実である。

（5）ガゼルの群れが一定の限られたルート以外を自由に通れる場合はカイトの効果む 半減する。その点では火山性の玄武岩塊に覆われ, その結果, ワディ以外の通行が容 易でない黒砂漠のような地域でとそカイトの設置は最も効果的である。カイトが黒砂 漠に最も高密度に分布している背景にはこうした地形上の理由があろう。てれに対し て西側の地域一帯やイラクなどでは一一動物遺存体の検出によって明らかなように, ガゼル自体は相当数生息していたにあ拘らず一一そてが平坦な沖積地を多く含むだけ に, カイトの設置効果は上がらない。従って, カイトの設置も余り意味を成さないて とになるが，そのことはカイトの分布に端的に示されている。とのようにカイトは内 陸部の特殊な地形を逆手に取った実に巧妙な狩猟方法である。また同じ内陸部で，し かも先土器新石器文化の遺跡が確認されている地域でありながら, カイトの有無或は 多寡に大きな差が認められるのもカイト対する地形の適, 不適が原因ではないかと考 えられる。例えば, 先土器新石器文化の遺跡が多く確認されているパルミラ盆地やエ ル・コウン盆地におけるカイトの欠如（或は稀少）もその比較的平坦な地形が逆に災 いしたあのと思われるのである。なおてれに付け加えるとすれば，カイトの築造材之 しての岩の入手の問題が挙げられよう。この点でもやはり黒砂漠は有利で, 沖積地は 不利であろう。

\section{引用文献}

Adams, R. C., Parr, P. J., Ibrāhīm, M. and al-Mughannum, A. S. 
1977 Saudi Arabian Archaeological Reconnaissance, 1976, Atlal, Vol. 1, pp. 21-40. Akazawa, T.

1979 Flint Factory Sites in Palmyra Basin, In Hanihara, K. and Akazawa, T., eds., 1979 Paleolithic Site of the Douara Cave and Paleogeography of Palmyra Basin, part II: Prehistoric Occurences and Chronology in Palmyra Basin, The University Museum, The University of Tokyo, Bulletin, No. 16, pp. 159-200.

Aurenche, O., Cauvin, J., Gauvin, M.-C., Copeland, L., Hours, F. and Sanlaville, P. 1981 Chronologie et Organization de l'Espace dans le Proche Orient de 12000 à 5600 av. J. C. (14000 à 7600 BP.). In Centre National de la Recherche Scientifique ed., Préhistoire du Levant, pp. 571-601, Paris.

Betts, A.

1982 Prehistoric Sites at Qa' a Mejalla, Eastern Jordan, Levant, Vol. XIV, pp. 1-34.

1983 Black Desert Survey, Jordan: First Preliminary Report, Levant, Vol. XV, pp. $1-10$.

1984 Black Desert Survey, Jordan: Second Preliminary Report, Levant, Vol. XVI, pp. 25-34.

1985 Black Desert Survey, Jordan: Third Preliminary Report, Levant, Vol. XVII, pp. 29-52.

Cauvin, J.

1981 L' Occupation Néolithique de la Région d' el Kown: Résultats 1978-1979, In Centre National de la Recherche Scientifique ed., Préhistoire du Levant, pp. 471-483, Paris.

Cauvin, J., Cauvin, M.-C. and Stordeur, D.

1979 Recherches Préhistoriques à el Kown (Syrie), Première Campagne 1978, Cahier de l'Euphrate, No. 2, pp. 80-117.

Field, H.

1960 North Arabian Desert Archaeological Survey, 1925-50, Papers of the Peabody Museum of Archaeology and Ethnology, Harvard University, Vol. XLV, No. 2.

Garrard, A., Byrd, B., Harvey, P. and Hivernel, F.

1985 Prehistoric Enviroment and Settlement in the Azraq Basin; A Report on the 1982 Survey Region, Levant, Vol. XVII, pp. 1-28.

Harding, L.

1953 The Cairn of Hani, Annual of the Department of Antiquities of Jordan, Vol. 2, pp. 8-56.

Helms, S. W.

1975 Jawa 1973: A Preliminary Report, Levant, Vol. VII, pp. 20-38.

1976 Jawa Excavations 1974: A Preliminary Report, Levant, Vol. VIII, pp. 1-35.

1977 Jawa Excavations 1975: Third Preliminary Repoort, Levant, IX, pp. 21-35.

1981 Jawa: Lost City of the Black Desert, London. 
Legge, A. J.

1975 Appendix B; The Fauna of Tell Abu Hureyra: Preliminary Analysis, Proceeding of Prehistoric Society, Vol. 41, pp. 74-76.

Maitland, F.-L.

1927 The "Works of the Old Men" in Arabia, Antiquity, Vol. I, pp. 197-203.

Meshel, Z.

1974 New Data about the "Desert Kites", Tel Aviv, Vol. I, pp. 129-143.

Parr, P. J., Zarins, J., Ibrāhīm, M., Waechter, J., Garrard, A., Clarke, C., Bidmead, M. and al-Badr, $\mathrm{H}$.

1978 Preliminary Report on the Second Phase of the Northern Province Survey 1397/1977, Atlal, Vol. 2, pp. 29-50.

Prag, K.

1985 Ancient and Modern Pastoral Migration in the Levant, Levant, Vol. XVII, pp. 81-88.

Rees, L. W. B.

1929 The Transjordan Desert, Antiquity, Vol. III, pp. 389-407.

Rollefson, G. O.

1983 The Seasons of Excavations at 'Ain el-Assad near Azraq, Eastern Jordan, 1980-1981, Bulletin of the American Schools of Oriental Research, Vol. 252, pp. 25-34.

1984 'Ain Ghazal: An Early Neolithic Community in Highland Jordan, Near Amman, Bulletin of the American Schools of Oriental Research, Vol. 255, pp. 3-14.

Rollefson, G. O. and Fröhlich, B.

1982 A PPNB Burin Site on Jabal Uweinid, Eastern Jordan, Annual of the Department of Antiquities of Jordan, Vol. XXVI, pp. 189-198.

Rollefson, G. O. and Kafafi, Z.

1985 Khirbet Hammam: A PPNB Village in the Wadi el-Hasa, Southern Jordan, Bulletin of the American Schools of Oriental Research, Vol. 258, pp. 63-69.

Rollefson, G. O. and Simmons, A. H.

1984 The 1983 Season at Ain Ghazal, Preliminary Report, Annual of the Department of Antiquities of Jordan, Vol. XXVIII, pp. 13-30.

Rothenberg, B.

1972 Timna: Valley of the Biblical Copper Mines, London.

Waechter, J. d' A. and Seton-Williams, V. H.

1938 The Excavations at Wadi Dhobai 1937-1938 and the Dhobaian Industry, Journal of the Palestine Oriental Society, Vol. 18, pp. 1-14.

Yadin, Y.

1955 The Earliest Record of Egyptian Military Penetration into Asia?, Israel Exploration Journal, Vol. 5, pp. 1-16.

藤井純夫 
1981 「レヴァント初期農耕文化の研究」『岡山市立オリエント美術館研究紀要』第 1 巻, 1-87頁, 岡山。

1983 「鎌刃の装着法分類」『古代オリエント博物館研究紀要』第 5 巻，129-152 頁, 東京。

1987 「ビュラン・サイトーーレヴァント地方先土器新石器文化の一側面」『岡山市立 オリエント美術館研究紀要』第 6 巻, 47-73頁, 岡山。

なお，後藤健氏（古代オリエント博物館）にはサウジアラビアに関する文献を拝借さ せていただいた。また西秋良宏氏（東京大学大学院）には文献複写の労を採っていただ いた。共に記して感謝申し上げる次第である。

（追記） 本稿脱稿後, 今村啓爾氏（東京大学文学部助手）より, 我が国縄文時代の陥穴

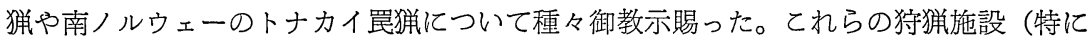
後者）には本稿で述べたカイトと共通する点が多々あり，西アジアのカイト・サイトを 理解する上であ大いに参考になると思われたが，今回は時間の関係で反映するてとがで きなかった。今村氏にはての場を借りてお詫び申し上げると共に，丁寧なる御教示に対 して御礼申し上げる次第である。なお，筆者が御教示賜ったのは下記の論文である。

Barth, E. V., 1983, Trapping reindeer in South Norway, Antiquity, Vol. LVII, pp. 109-115.

な打同論文は，エドヴァルト・K・バルト著，今村啓爾氏訳，1985「南ノルウェーの トナカイ罠編」として『歴史公論』第 11 巻 5 号，114-125頁（雄山閣）に翻訳紹介され ている。

一方の縄文時代の陥穴铍については文献数が多いので省略させていただく。詳しくは， 今村啓爾, 1983 (陥穴 (抢とし穴)「(加藤晋平, 小林達雄, 藤本強編集『縄文文化の研 究』第 2 巻，148-160頁，雄山閣）の末尾に揭げられた引用文献目録を参照されたい。 


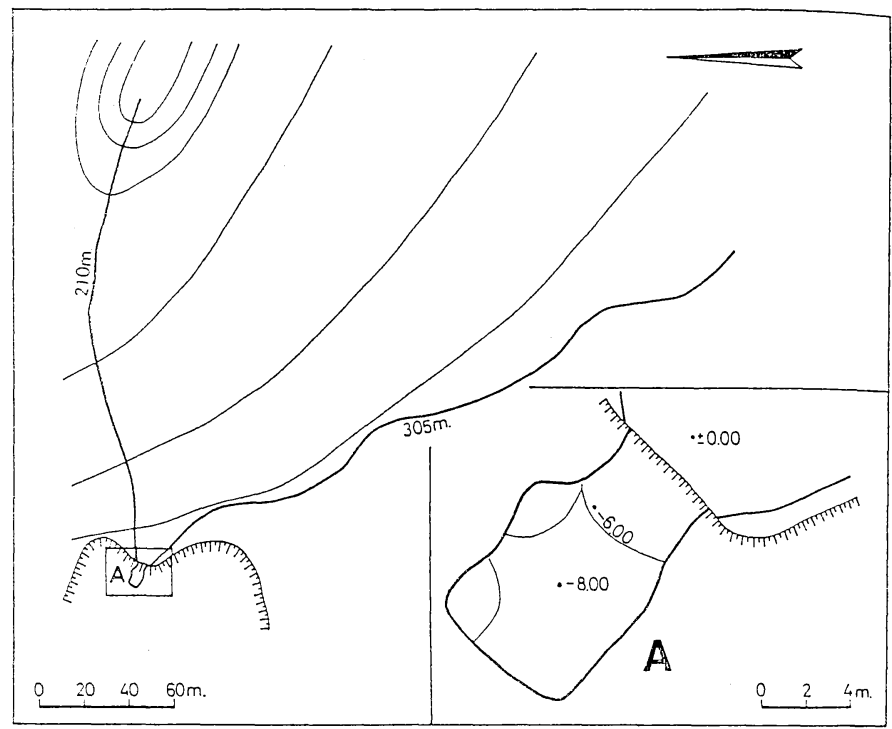

図 1 シナイ半島, アラユィフ・エン・ナカ山のカイト (Meshel 1974)

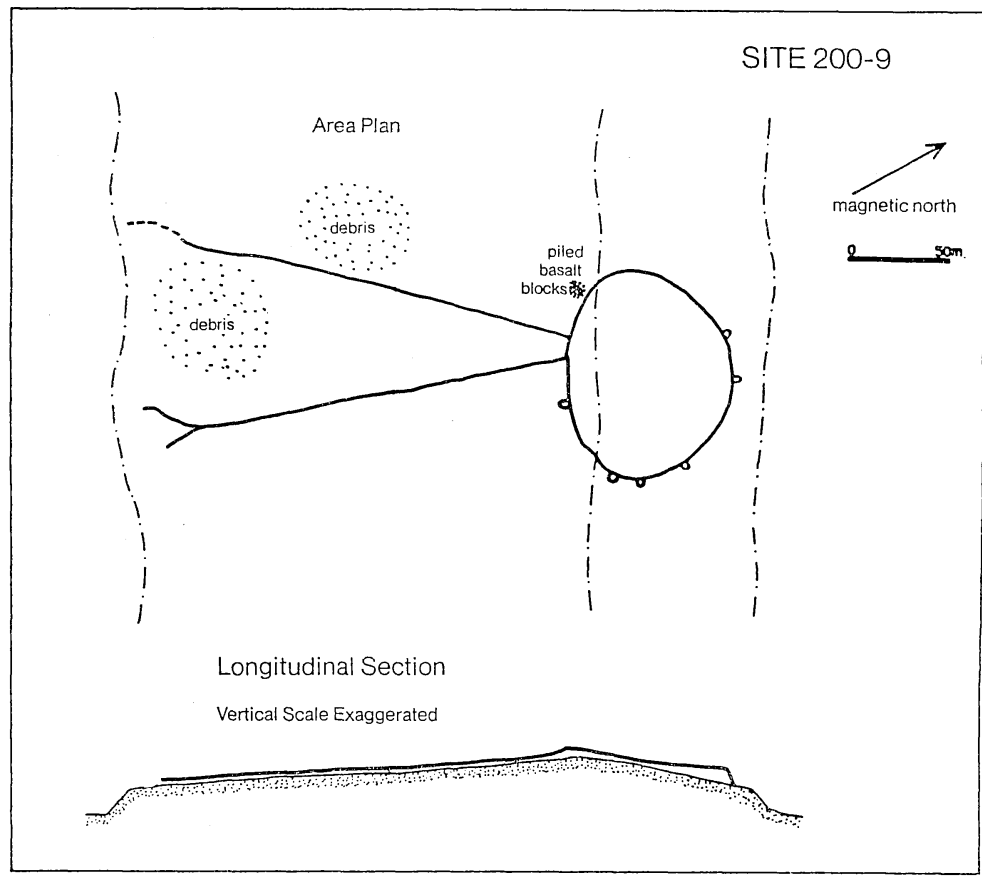

図 2 サウジアラビア, Site 200-9 のカイト (Adams et al. 1977) 


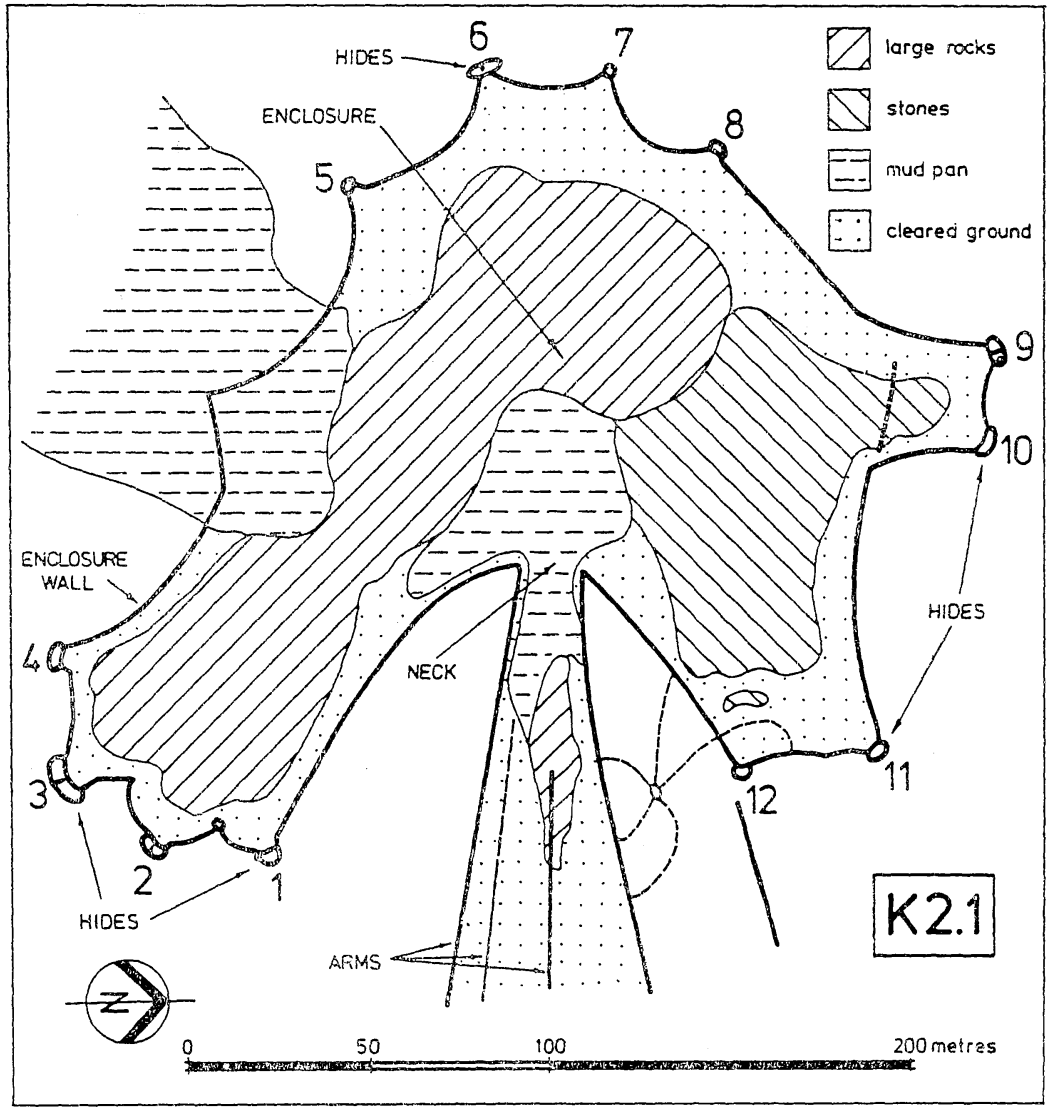

図 3 ヨルダン領黒砂漠のカイト，K. 2. 1 (Helms 1981)
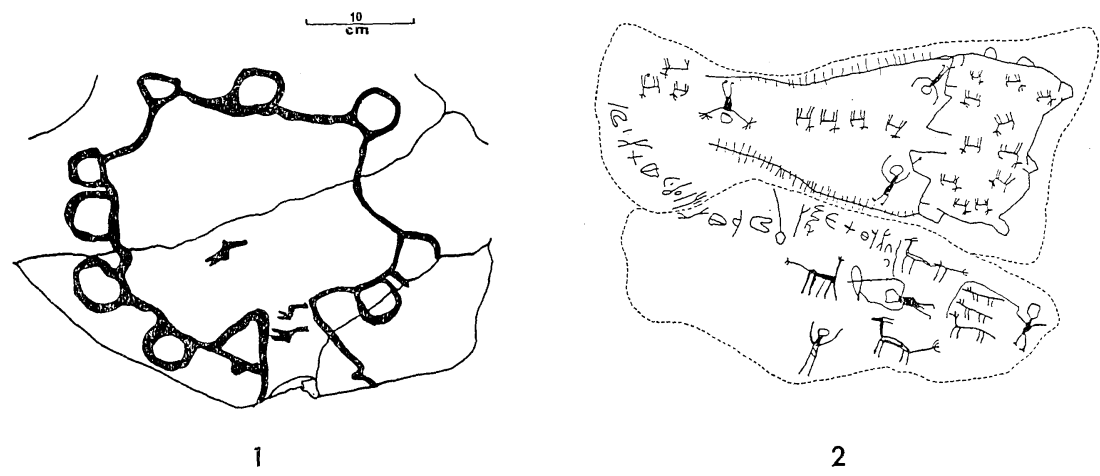

図 4 岩刻面に描かれたカイト (1: Harding 1953, 2: Betts 9184) 


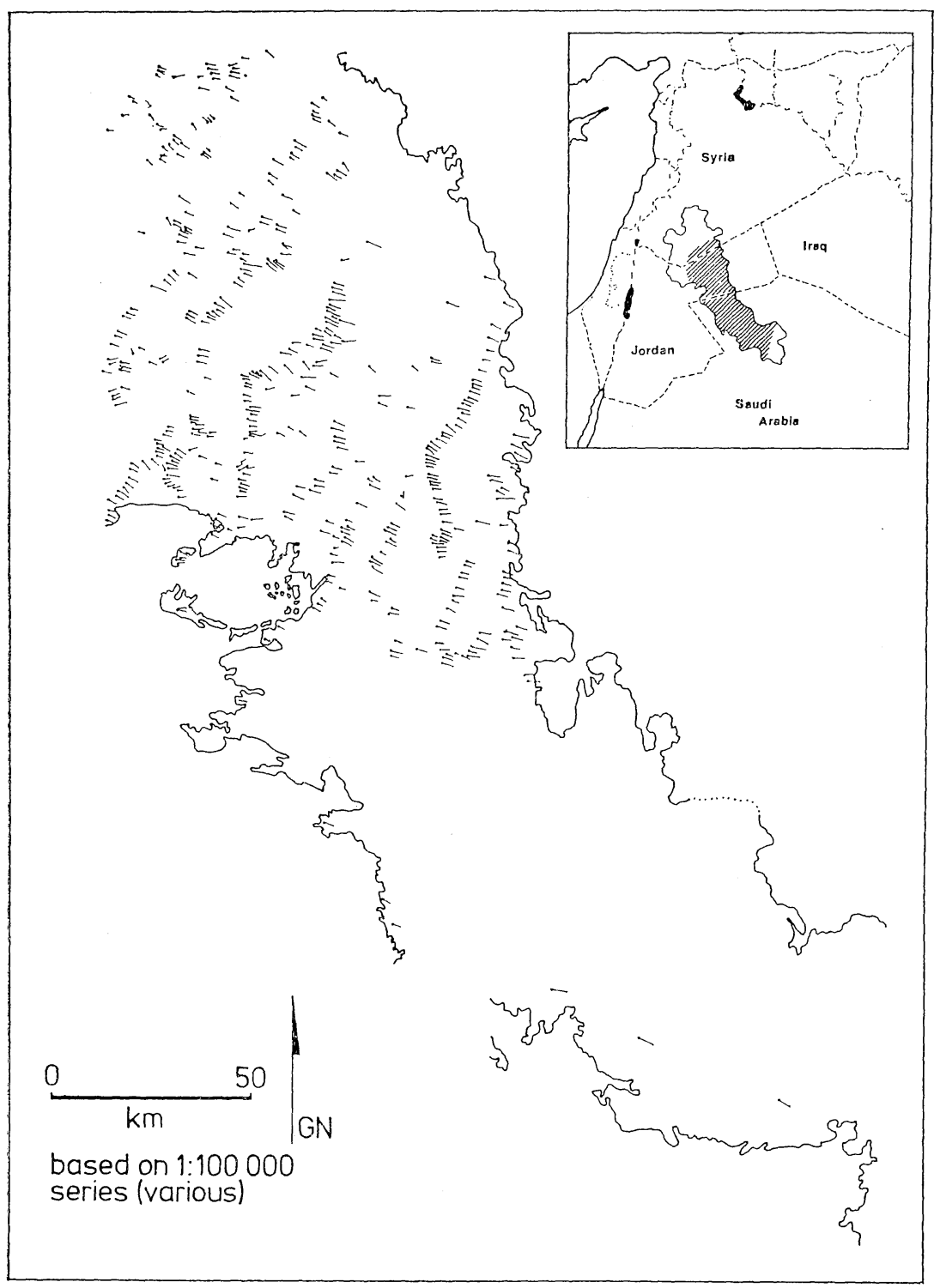

図 5 カイトの分布図 (1) (Betts 1985) 


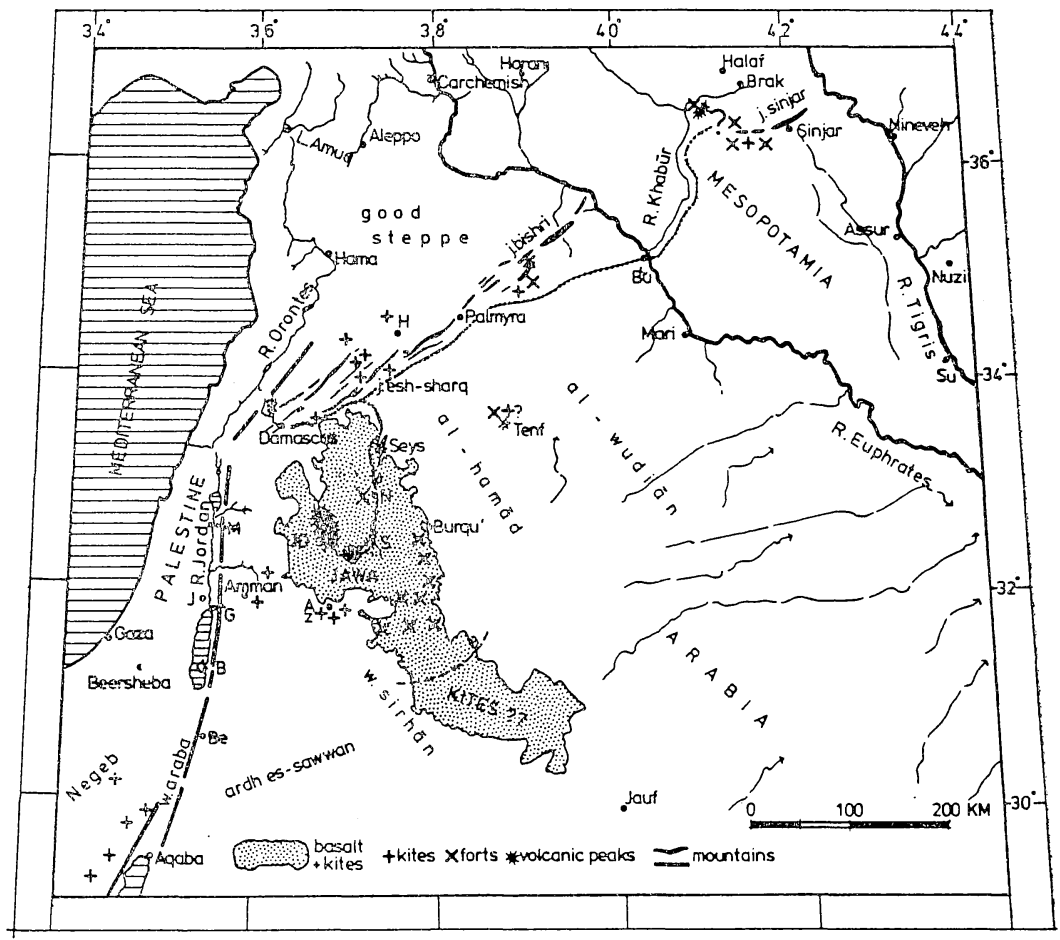

図6 カイトの分布図 (2) (Helms 1981)

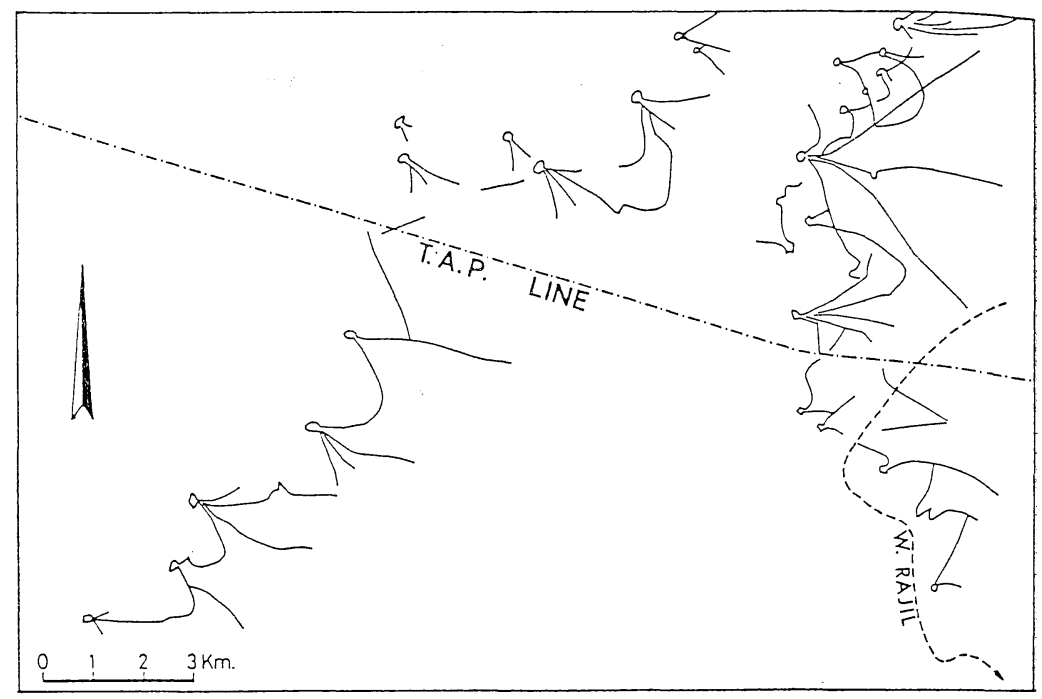

図 7 連結型のカイト (Meshel 1974) 

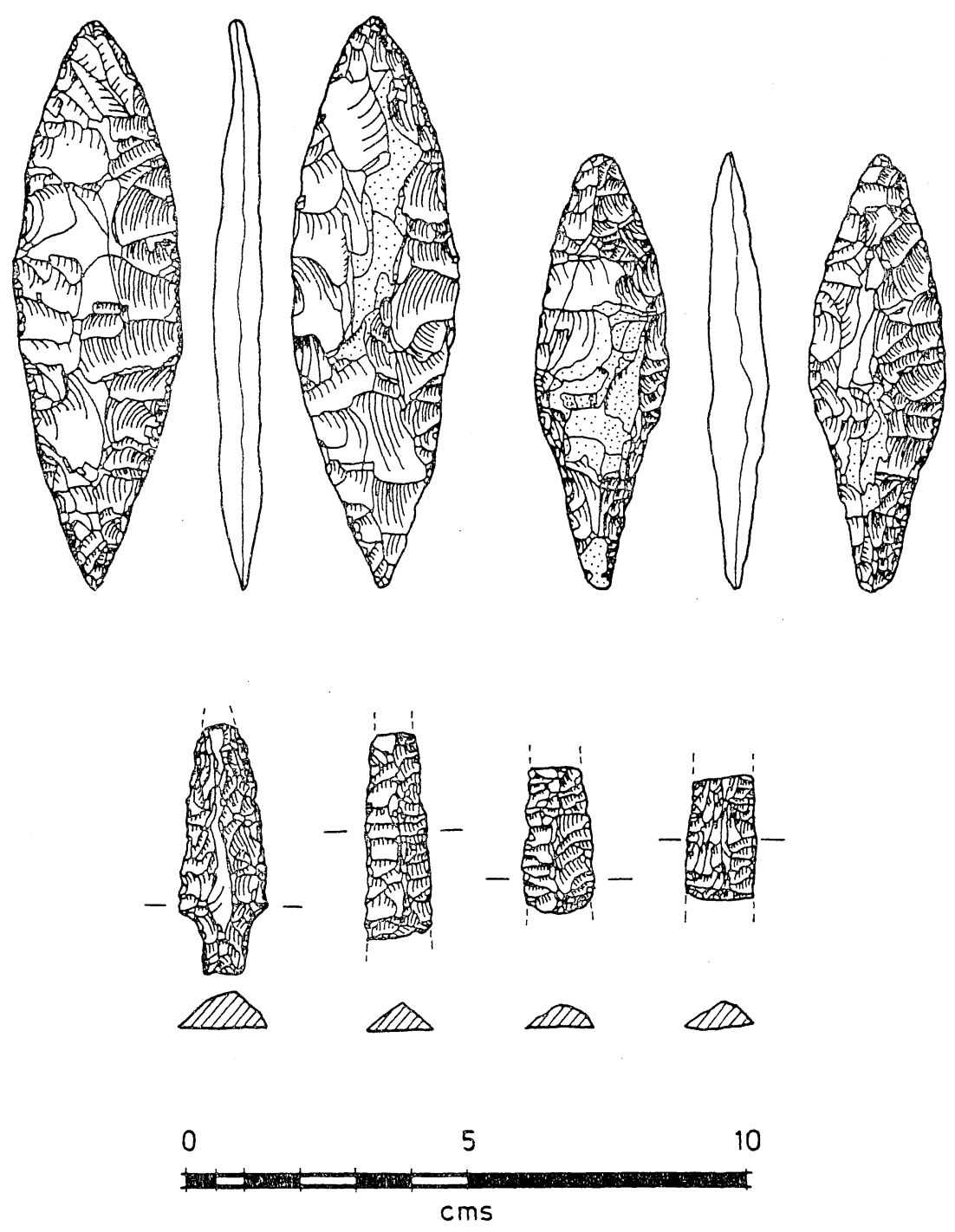

図 8 カイトの共伴遺物 (Helms 1981) 


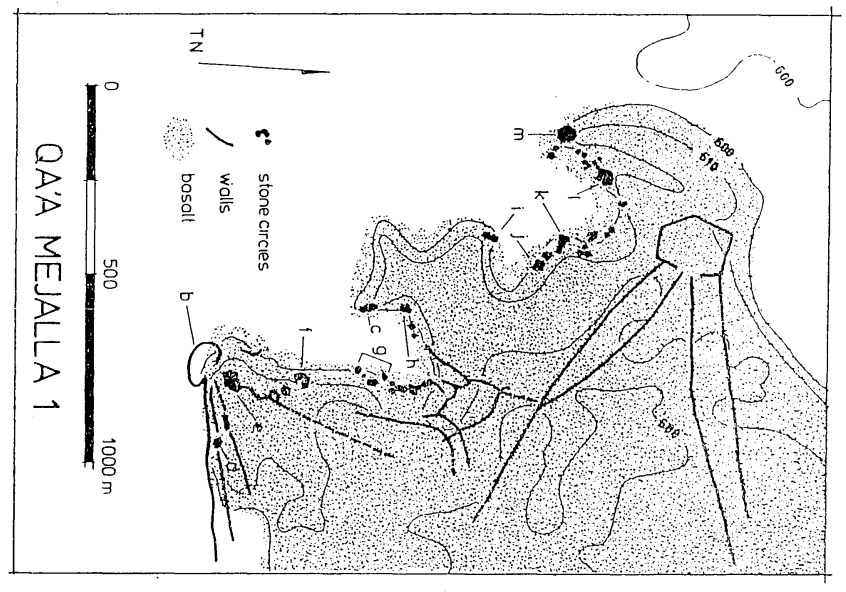

図 9 カア・メジャラ 1 地区の遺跡分布 (Betts 1982)

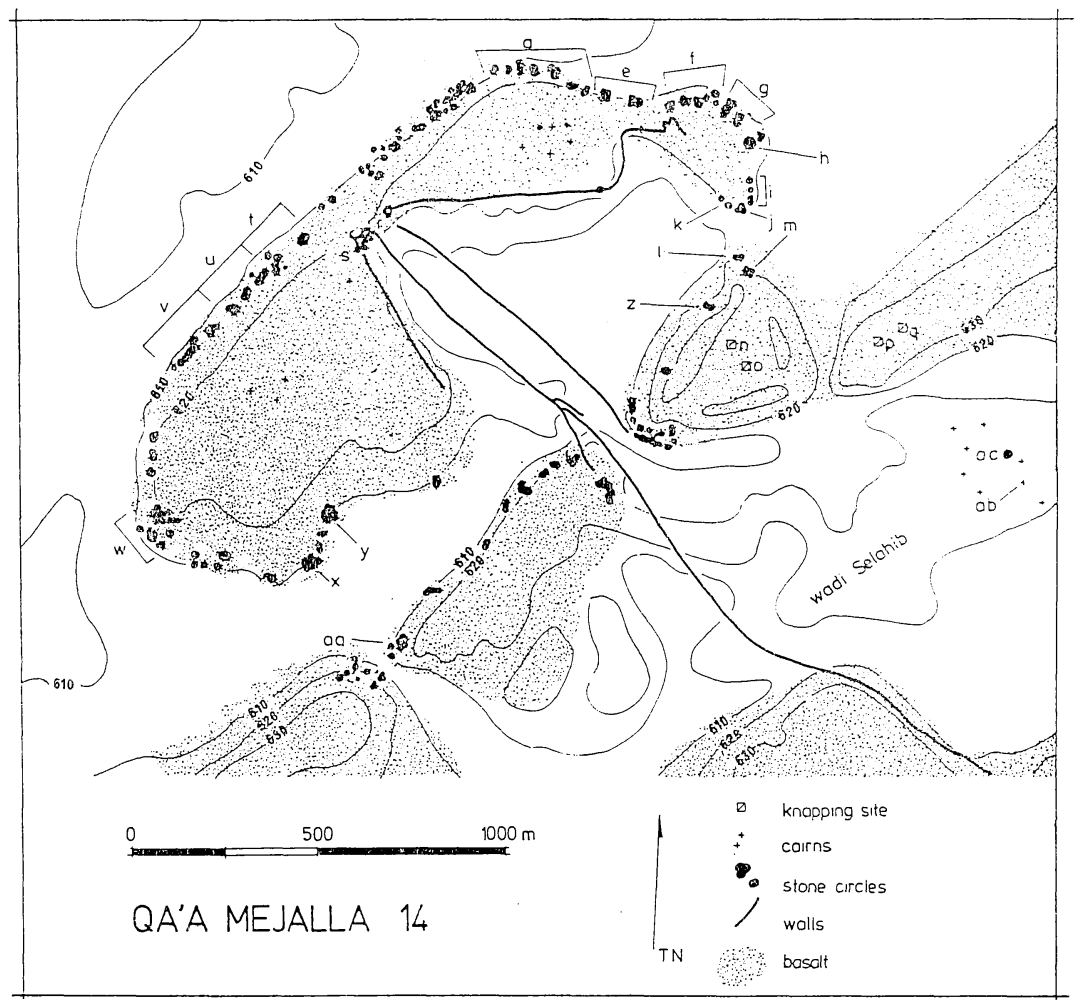

図10 カア・メジャラ14地区の遺跡分布（Betts 1982） 